\title{
Empirical analysis of legal institutions and institutional change: multiple-methods approaches and their application to corporate governance research
}

\author{
JOHN BUCHANAN* \\ Centre for Business Research, University of Cambridge, Cambridge, UK \\ DOMINIC HEESANG CHAI** \\ Graduate School of Business, Seoul National University, Seoul, Republic of Korea \\ SIMON DEAKIN ${ }^{* * *}$ \\ Centre for Business Research, University of Cambridge, Cambridge, UK
}

\begin{abstract}
The claim that institutions matter for economic growth and development has so far received a more extensive theoretical treatment than an empirical or methodological one. Basing our approach on a coevolutionary conception of relations between law and the economy, we link theory to method and explore three techniques for analysing legal institutions empirically: 'leximetric' measurement of legal rules, time-series econometrics and interview-based fieldwork. We argue that while robust measurement of institutions is possible, quantitative techniques have their limits, and should be combined with fieldwork in a multiple-methods approach.
\end{abstract}

\section{Introduction}

As a result of the flowering of institutional research in the past three decades, associated with the rise of new institutional economics and with developments in related interdisciplinary fields including the economics of law, there is now considerable agreement among social scientists on the nature of institutions and on their potential to shape economic and social outcomes. The following propositions command broad assent: institutions are systems of norms or rules that set prescriptive standards for behaviour (Greif, 2006; Hodgson, 2006; North, 1990); they are characterised by varying degrees of formality, ranging from formal legal rules at one extreme to social norms and conventions at the other (Ostrom, 2005); they are functional, by virtue of reducing transaction

\footnotetext{
*Email: jsb50@cam.ac.uk

**Email: dchai@snu.ac.kr

***Email: s.deakin@cbr.cam.ac.uk
} 
costs associated with production and exchange (Coase, 1988; Williamson, 1985); they both reflect behaviour, in the sense of being endogenous to their context or environment over the long term (Aoki, 2007, 2010) and shape it, in the sense of constraining or channelling agents' choices or options in the short term (North, 1990); they are stable while also displaying adaptive or evolutionary tendencies (Hodgson, 2006); they change over time but cannot straightforwardly be redesigned through conscious action (Voigt, 2013). There is also an emerging consensus around the basic elements of an integrated theory of institutions and institutional change: this would combine an analysis of micro-level interactions of agents based on evolutionary and epistemic game theory, with an understanding of the emergent properties of macro-level structures, drawing on the theory of complex systems (Aoki, 2010; Gindis, 2009; Hédoin, 2012).

These tendencies towards theoretical refinement and synthesis notwithstanding, there is a gap in the literature on institutions that threatens to derail the wider project. This is the absence of a convincing account linking the theory of institutions to a set of empirical methods for measuring institutions and identifying their precise roles in shaping economic behaviour and outcomes. As Voigt (2013: 1-2) has recently pointed out, if we cannot firstly isolate institutions from other societal phenomena (a theoretical issue) and secondly subject them to systematic empirical analysis (a methodological issue), we can neither substantiate nor refute the core claim that 'institutions matter' for economic development and growth.

In this paper we aim to take up the challenge of how firstly to theorise and then to measure institutions in the context of empirical research on contemporary systems of corporate governance, with specific reference to the role of the law. Section 2 addresses some theoretical issues around the definition and identification of legal institutions. We argue for an ontological perspective that sees legal institutions not only as endogenous to their context, but also as more than simply an expression of behavioural phenomena; rather, they shape behaviour and thereby operate, potentially at least, as independent causal variables, capable of affecting economic outcomes. We then go on to consider three complementary methods for measuring and, more generally, empirically analysing legal institutions, so defined. The first, which we term 'leximetric' after Lele and Siems (2007), sets out to quantify legal and other formal rules, with a view to gaining insight into the degree of variation across the legal and regulatory environments of different countries, regions and industries (Section 3 ). The second, econometric analysis, attempts to use econometric techniques in order to isolate the causal effects of institutions, in particular their impact on the economic performance of firms, regions and nations (Section 4). The third, case-study research using interview-based fieldwork, provides access to actors' beliefs and perceptions of the operation of formal and informal norms, beyond what can be achieved through econometric analysis (Section 5). The first of these techniques, leximetric analysis, is relatively new, and still unfamiliar to many 
social scientists. The second two are far from unfamiliar, but we will argue that their application in the context of research on institutions raises distinct issues, which require novel treatment. We will moreover argue that while it is possible to measure some institutional phenomena in a methodologically robust way, quantitative analysis of institutions, on its own, suffers from significant limitations. We suggest, following Poteete et al. (2010), that statistical research should be combined with qualitative and narrative methods if understanding of institutions is to be advanced. At each step in our analysis we illustrate our argument by reference to recent research in corporate governance. Corporate governance is not the only field in which multiple methods have recently been applied in such a way as to throw light on the economic role of legal institutions (labour regulation is another: see Deakin and Sarkar 2008), but it is one of the most research-active, and so provides an informative context in which to locate our discussion. Section 6 concludes.

\section{Theorising the role of law in corporate governance}

A narrow if popular definition of 'corporate governance' is that it is concerned with the 'ways in which suppliers of finance to corporations assure themselves of getting a return on their investments' (Shleifer and Vishny, 1997: 737). One means of achieving this end, which is stressed by the 'legal origins' literature from which the definition just given is derived, is through legal rules protecting the rights of shareholders. Beginning in the late 1990s, studies based on multicountry panel data regressions began to report correlations between the extent of legally mandated shareholder protection, on the one hand, and various economic and financial indicators, on the other, including the equity value of firms whose shares were traded on public markets, and the predominant structure of share ownership in different countries. Specifically, legal support for shareholders' rights to exercise voice in the running of the firm, to enjoy the surplus from production in the form of dividends and similar income flows, and to take control of the assets of the firm through a takeover or merger, was shown to be correlated with higher equity values, increased capital market liquidity and more dispersed share ownership (La Porta et al., 1998, 2008).

The narrow definition of corporate governance is related to an equally narrow, functionalist view of corporate law, which is seen as operating to reduce the agency costs arising from the delegation of tasks from 'principals', here the shareholders, to their 'agents', in this case the managers. It is possible to take a broader view of corporate or enterprise governance that avoids ascribing a single or predominant function to the law. This is one that sees the firm as an economic organisation that is structured by a number of legal institutions, of which the 'corporation' is one (Robé, 2011: 5). Company law, along with other aspects of the law governing firms such as employment law and fiscal law, is both a reflection of the economic form of the business enterprise (Deakin, 2003), and 
an external influence, capable of shaping the behaviour of corporate actors in the ways suggested by legal origins theory and also, potentially, in other ways.

To see the necessity for this broader view, it is helpful to consider the undefined term in the definition of corporate governance offered by Shleifer and Vishny (1997), namely the 'corporation' itself. The corporation has a clear legal definition, associated with the juridical concepts of separate legal personality and limited liability, which perform a number of interlocking economic functions, such as partitioning assets and more generally allocating property rights in ways that facilitate economic coordination (Armour et al., 2009c). To say that the corporation has a legal form does not mean that it is solely a legal institution, however. The legal institution coexists with, and is related to, a social institution. Writing from a game theoretical perspective, Aoki (2010:9) suggests that the corporation's legal identity can be thought of as a 'representation' of its features as a self-organising, associational entity within the social domain. Similarly, a systems-theoretical view of law sees the 'juridical' definition of the corporation as a linguistic device through which the rules of the legal system governing business enterprises are mobilised (Deakin and Carvalho, 2011).

In this context, the term 'juridical' refers to the distinctive, internal language of legal discourse, through which legal meaning is ascribed to economic and other social forms. Systems theory in the sociology of law, which can be thought of for present purposes as providing a complementary perspective to that of new institutional economics, stresses the incomplete and contingent nature of any 'fit' between the law and the economy. The study of legal concepts may tell social scientists something about the economic nature of the corporation (Gindis, 2009), but only at one remove. The law uses a 'special, juridical semantics' (Luhmann, 2004: 314) that does not have a one-to-one correspondence with economic relations. Thus rather than adjusting to economic change in a linear way, the law 'coevolves' with the economy, each system responding in a contingent and incomplete way to changes in the other (Luhmann, 2004: 400).

This view implies that the law is not just a function of, or an expression of, an underlying economic 'reality'. The legal meanings attributed to a term such as 'corporation' are distinct from those used in an economic or business context. These legal meanings should be studied using the interpretive techniques associated with legal-doctrinal analysis. Legal mechanisms of various kinds, such as property rights, liability rules and modes of regulation, may have an independent impact on actors' behaviour. These social and economic effects should be analysed using the techniques of the empirical social sciences. When moving from doctrinal to empirical analysis, the boundary between rules that have a legal character and those that do not may well appear more porous than it does in conceptual legal analysis; thus an empirical strategy for understanding legal rules should take into account their inter-relationship with social norms, self-enforcing conventions and other behavioural regularities that do not attract legal sanctions and that in a juridical sense are beyond the limits of legal 
discourse. A long tradition in the empirical sociology of law stresses the importance of studying this 'living law' (Ehrlich, 1936) without dissolving legal rules into the category of social norms, or neglecting the role of the sanctions that are attached to legal rules but that have no application to extra-legal norms or mere behavioural regularities.

We shall now consider more precisely how that can be done. A first step is to examine contrasting approaches to the construction and analysis of legal datasets.

\section{3. 'Leximetrics': measuring legal rules}

According to Lele and Siems (2007: 1), adapting a definition first offered by Cooter and Ginsberg (2003), “leximetrics” can be understood as every quantitative measurement of law'. In the context of corporate governance research, the term has come to be associated with the measurement of legal rules protecting the rights of shareholders and other corporate stakeholders, including creditors and employees, in their dealings with and within the firm. The dataset described in Lele and Siems (2007) is one of a number of such data sources developed at the Centre for Business Research in Cambridge (henceforth the 'CBR datasets'). They differ from the widely used legal datasets constructed by La Porta, Lopez de Silanes, Shleifer and Vishny ('LLSV': see La Porta et al., 1998, 2008) in providing a time series of changes in the law. A comparison of the methods used in the two cases illustrates some of the challenges inherent in the project of measuring legal rules.

\section{Variable selection}

LLSV's anti-director rights index ('ADRI'), presented in their landmark paper on 'law and finance' (La Porta et al., 1998), was intended to capture the formal or de iure content of legal rules protecting shareholders from oppressive or discriminatory treatment on the part of the management or, more precisely, the board of the company. The extended ADRI consists of eight indicators that are meant to express how far shareholders can exercise voice and voting rights at a shareholders' meeting and how far they can require the board to release profits in the form of dividends. Two indicators that are missing from their index but that figure prominently in corporate governance codes of practice of around this period, such as the OECD Principles of Corporate Governance (1999, amended in 2004), are rules mandating independent board membership (on the theory that independent directors will better represent the interests of shareholders than executives will) and rules supporting hostile takeover bids (which in effect enable shareholders reallocate control of corporate assets away from underperforming managers).

An index such as the ADRI cannot, by definition, include every legal rule that touches on shareholder rights, and it may be that a small number of critical 
indicators can stand in as proxies for the system as a whole. There may be a more fundamental problem, however, with the ADRI, namely that it appears to reflect a 'home country bias' in the sense of focusing on rules that are by and large typical of common law (English-origin) systems, in particular the USA, and less typical of civil law (French-, German- and Scandinavian-origin) ones (Lele and Siems, 2007). To the extent that this is the case, one of the principal empirical findings to emerge from the analysis of La Porta et al. (1998), namely that countries with a common law origin protect shareholders' interests more extensively than those of civil law origin do, could be just a function of the (arguably idiosyncratic) selection of variables for inclusion in the index.

Lele and Siems (2007) present an alternative index of shareholder protection with 60 variables in it ('SPI-60'), grouped into two sub-indices. One covers rules that protect shareholders against dominance by the board. This addresses the core concern of the standard agency-theoretical model of the firm, namely the ability of shareholders to hold managers to account and to ensure that they receive a return that is commensurate to their investments. The second subindex in the SPI-60, on the other hand, measures rules that protect minority shareholders from oppression by a dominant 'blockholder' or majority owner of shares. This sub-index, then, looks at a different version of the agency problem, in which the core problem of coordination for the firm is not the ability of shareholders to exercise oversight over managers - this is less of an issue where there is a majority shareholder able to exercise power over the board - but the risk that the dominant blockholder will expropriate the minority shareholders.

The advantage of coding a wider range of legal rules and of distinguishing between these two contrasting types of shareholder protection is that some important variations in the composition of legal rules across common law and civil law countries start to become clear: shareholder protection of the first type is traditionally characteristic of common law countries, while protection of the second type historically characterises civil law ones (Armour et al., 2009a). With this new empirical information, LLSV's claim of the supposed superiority of the common law, in matters of shareholder rights at least, is put into perspective. Civil law systems have their own rules for shareholder protection, which respond to conditions in those countries, which are 'coordinated market economies' (after Hall and Soskice, 2001), mostly characterised by block shareholdings. In the common law, by contrast, company law has responded to the powers that relatively autonomous boards have over dispersed shareholders, a pattern distinctive to 'liberal market systems', by strengthening the shareholders' rights to hold management to account.

The time-series dimension of the Lele-Siems index (it covers the period 19702005) clarifies a number of other matters. It shows that there was a general increase, regardless of legal origin, in 'Type 1' shareholder protection (that is, protection of shareholders against the board) from mid-1990s onwards. There was no similar trend in relation to 'Type-2' protection (protection of minority 
Figure 1. Shareholder protection 1995-2005: developed, developing and transition systems. Source: CBR Shareholder Protection Index, 25 countries, 19952005 (http://www.cbr.cam.ac.uk/research/programme2/project2-20.htm).

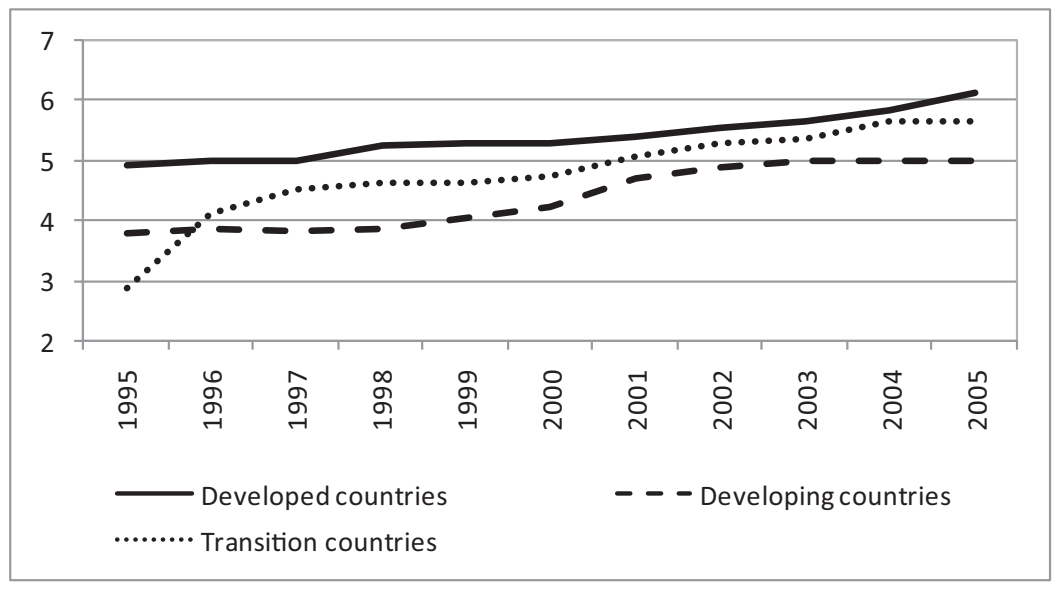

shareholders against blockholders). The picture is one of convergence of de iure laws, but around a model that originated in the common law.

The original Lele-Siems index covered five countries (France, Germany, UK, the USA, and India). The long time series and the large number of variables in the index were thought to justify a focus on this small number of systems, each of which merited close study in its own right. A variant of the original index was then constructed ('SPI-10': Armour et al., 2009b; Siems, 2008). This focused on Type- 1 protections, that is, laws protecting shareholders against management, using 10 indicators that were intended to capture the core of what, despite its common law origins, had become a 'global consensus' on shareholder protection from the early 1990s onwards. To this end, the indicators were drawn from texts of global relevance for corporate governance standards at this time, in particular the OECD's Principles of Corporate Governance. The index covered the period 1995-2005, which was chosen because of the strong indication from the earlier study (Lele and Siems, 2007) of a marked convergence of national systems beginning around this time. Thus the variables in this index were selected not because they were thought to be more representative of company law rules in general than others, but to test two specific hypotheses, namely that there had been a worldwide increase in a particular type of shareholder protection from the mid-1990s, and that this had discernible economic effects in terms of the promotion of financial development.

Figures 1 and 2 present the results of the analysis in graphical form, with regard to the first of these hypotheses (we return to the second one in Sections 4 and 5). They show that there was a marked 'catching up' between developing 
Figure 2. Shareholder protection 1995-2005: common law and civil law countries. Source: see Figure 1.

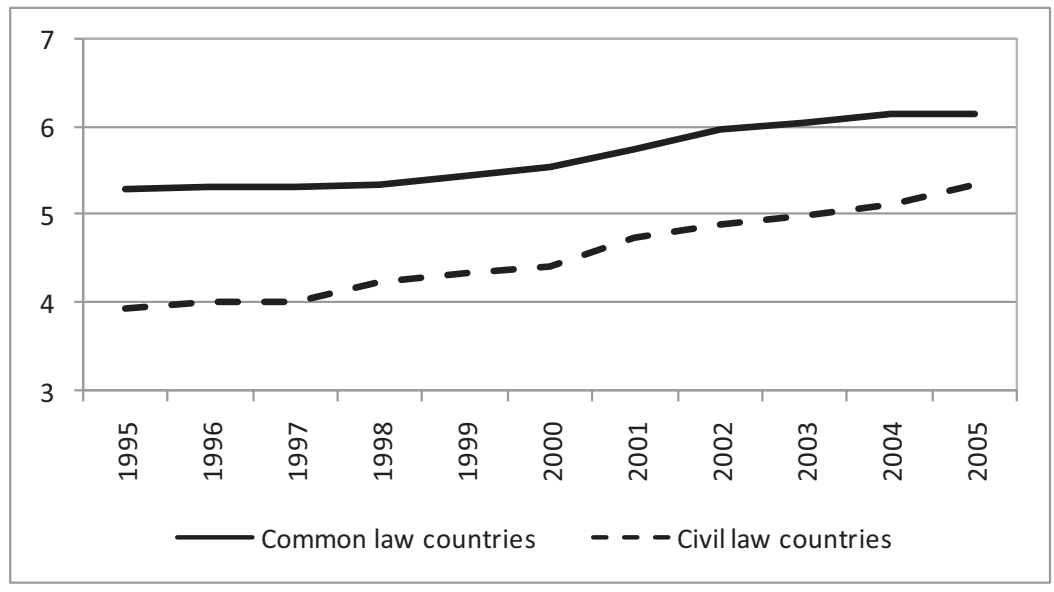

and transition systems, on the one hand, and developed countries, on the other (Figure 1), and between the civil law and the common law (Figure 2), over this period of time. Breaking down the trend by reference to individual indicators, the rules on independent boards and protection of shareholders during takeover bids experienced the greatest pro-shareholder shift (Armour et al., 2009a).

\section{Coding protocols}

The 'coding' of raw data into a form that makes it amenable to systematic analysis is a feature of all empirical social science research, whether quantitative or qualitative. In the case of 'leximetric' coding, the raw data consist of legal texts (judicial decisions, statutory provisions and other relevant textual statements of rules). To convert them into a usable form, it is necessary to employ coding 'protocols' or 'algorithms'. These define the relevant indicators and set out the processes to be followed in attributing numerical scores to them.

Table 1 sets out the definitions and coding algorithms used in constructing the indicators for board independence and takeover protection ('mandatory bid') in the SPI-10 index.

It can be seen from these excerpts that the SPI-10 is based on a fine-grained approach to coding, in which an attempt is made to capture the degree of variation in the strength of a rule by using continuous or graduated scores on a $0-1$ scale, as opposed to the dichotomous or binary ones used by La Porta et al. (1998). The justification for taking the former approach is that legal rules are rarely a matter of all or nothing. The general coding protocols for the SPI-10 index aim at a further level of specificity, by aiming to distinguish between rules according to whether they are mandatory or optional. While some company law rules are formally mandatory, many more, as we have seen (in Section 2), are 
Table 1. Coding protocols for board independence and shareholder protection during takeover bids, SPI-10

\begin{tabular}{|c|c|}
\hline Independent board members & $\begin{array}{l}\text { Equals } 1 \text { if at least half of the board members must be independent; } \\
\text { equals } 0.5 \text { if } 25 \% \text { of them must be independent; equals } 0 \text { otherwise. }\end{array}$ \\
\hline Mandatory bid & $\begin{array}{l}\text { Equals } 1 \text { if there is a mandatory public bid for the entirety of shares in } \\
\text { case of purchase of } 30 \% \text { or one-third of the shares; equals } 0.5 \text { if the } \\
\text { mandatory bid is triggered at a higher percentage (such as } 40 \% \text { or } \\
50 \% \text { ); further, it equals } 0.5 \text { if there is a mandatory bid but the bidder } \\
\text { is only required to buy part of the shares; equals } 0 \text { if there is no } \\
\text { mandatory bid at all. }\end{array}$ \\
\hline
\end{tabular}

Source: Siems (2008).

'default rules' that the parties can opt out of. But even default rules come in many different forms: some can be customised or avoided at low cost, others less so. The relative degree of 'stickiness' of a default rule, expressed in terms of its legal form (we will come to its actual effect later: see Section 4), can in principle be incorporated into the score it receives (see Armour et al., 2009a; Siems, 2008). In addition, the SPI-10 codes for rules set out in corporate governance codes that do not, generally, take the form of rules of the legal system per se; they are the result of self-regulation by financial actors rather than judicial decision or legislative action, and they do not trigger civil or criminal legal sanctions if they are breached. From a juridical perspective, such rules are beyond the reach of the legal system, but from an empirical perspective they should be coded, since extra-legal rules in one country context may well be the functional equivalents of legal rules in another one (Zweigert and Kötz, 1992).

\section{Transparency of coding}

In the case of the SPI-10 and the other CBR datasets, leximetric coding has been carried out by teams of legal researchers, using coding protocols they themselves have designed. The final scores attributed to particular indicators represent a consensus arrived at by these researchers. It may be objected that the scores represent subjective evaluations, which cannot be independently replicated or validated. It has to be accepted that there is a degree of subjectivity in the creation of leximetric datasets such as these. However, the CBR datasets have been published online with a full account of the relevant legal sources for the scores, so that the results can be externally assessed. Since the first appearance online of these datasets, their methodology has been independently adopted by a number of other research teams (see Anderson et al., 2012). This suggests that the methods used enjoy a degree of consensus in the wider legal and social science research communities.

A reduction of subjectivity in coding can be achieved by a number of means, such as canvassing the views of a wider range of legal experts to get a consensus on scores (Spamann, 2010), polling legal practitioners for their opinions on the 
operation of particular legal rules (Djankov et al., 2008) and obtaining survey evidence on perceptions of legal protections (Chor and Freeman, 2005). These methods should be used where they are available, as they offer a potential check on results obtained from more interpretive approaches. But even then, the results remain 'hypothetical' in the sense of being based on beliefs rather than the 'real situation in individual countries' (Voigt, 2013: 19). In some cases, even these limited methods are not available. This is generally the case with time-series analysis. The CBR datasets code for lengthy time series, approaching 40 years in some cases (see Armour et al., 2009b). It is not plausible to rely on actors' perceptions today of the law several years or decades ago to code these data.

\section{Measuring de iure and de facto legal regulation}

It can be argued that the existence of a legal text, in itself, says little or nothing about its operation at the level of social practice. Several indices and related datasets purport to measure the general level of respect for legal rules in different countries. These include measures of the 'rule of law' constructed by the World Bank (Kaufmann et al., 2008) and the World Justice Project (http: //worldjusticeproject.org/rule-of-law-index/), both of which rely principally on survey data as opposed to textual sources, and which attempt to decompose different elements of respect for legality.

However, reliance on these measures does not obviate the need for some understanding of cross-national differences in de iure rules. If the focus is just on implementation, potentially significant differences in the content of rules will not be captured (Voigt, 2013: 10). Moreover, de iure laws may be good proxies for de facto ones. This will be the case where there is a high level of respect for the law in a given society. Even in a context where respect for the law cannot be assumed, it may be important to code for de iure and de facto law separately, in order to isolate the relative contribution of each to cross-national differences in institutional environments (Armour et al., 2009a).

A further consideration is that it may be very difficult in practice to get a reliable, general measure of the de facto operation of a given rule. It is tempting to think that this can be achieved by measuring the extent to which the law is 'enforced', and, relatedly, to distinguish between institutions according to the different modes of enforcement they incorporate (Shirley, 2013; Voigt, 2012). Measures of enforcement may be derived from data on court costs, litigation rates, and severity and frequency of sanctions. However, it is not at all clear that a high level of 'enforcement' indicates effective implementation of a rule. It is just as likely to indicate the opposite, on the grounds that rules that enjoy legitimacy in a given population of actors are, for that reason, much less likely to need strong enforcement, and so be more effective in practice, than rules that do not have such acceptance. Severe sanctioning may be counter-productive where it induces avoidance from those to whom public regulations are addressed and undermines private regulation; in practice, the most effective enforcement regimes combine 
punishment and persuasion (Braithwaite, 2006). Enforcement measures may however be usefully combined with measures of de iure law in environments where it is known that laws lack the support of all or some actors or where there is evidence of widespread non-implementation of the law (Fagernäs, 2010).

\section{Econometric analysis of the consequences (and causes) of legal change}

The quantification of legal rules through leximetric analysis is not done for its own sake, but in order to facilitate statistical testing of posited relationships between legal rules and institutions, on the one hand, and economic outcomes, on the other. Legal origins theory posits the existence of a causal relationship running from legal origin, represented by the common law or civil law 'origin' of a given country's legal system, to legal rules, such as the rules of company law governing shareholder rights, to economic outcomes, as evidenced, for example, by an observed statistical correlation between shareholder rights, on the one hand, and dispersed shareholder ownership and greater reliance by firms on equity finance, on the other (La Porta et al., 1998, 2008).

Legal origins theory in effect 'unbundles' two different aspects of legal institutions, namely the 'infrastructure' of a legal system, in terms of its constitutional framework and mechanisms for law-making, and the substantive rules governing a particular area of social or economic life (on the importance of unbundling; see Acemoglu and Johnson, 2005). There are limits to the unbundling, however, since legal origins theory claims that the many different elements of legal infrastructure can be captured by the binary divide between common law and civil law systems, with some allowance for differences between French-origin and German-origin systems in the case of the latter (La Porta et al., 2008). The basis for this is the claim that, in common law-origin countries, courts are the main source of rules, whereas in civil law ones, the legislature is the dominant rule-making institution. Following Hayek (1982), it is then further argued that common law rule-making methods are more likely to produce efficient rules, that is, rules that are matched to the needs of actors in a market economy.

In the legal origins approach, theory and empirical testing are intertwined; the validity of the theoretical claim is dependent upon a particular approach to econometric analysis. This is one that posits an invariant or at least stable relationship between an independent or causal legal variable, on the one hand, and a dependent or outcome economic variable, on the other, after controlling for a number of potentially relevant background factors, such as respect for the rule of law, level of economic development and so on. Tests of statistical significance of the kind that are standard in multiple regression analysis (chisquare tests, $t$-statistics and so on) are deployed in order to show that observed correlations are not an arbitrary feature of the regression model or statistical sample (see the survey in La Porta et al., 2008). 
Even so, in the context of institutional analysis, multiple regression analysis runs up against a serious problem, in the form of the 'endogeneity' of legal rules to their economic context. If it is plausible to see legal rules as shaped by, as opposed to shaping, features of the economy, then the observed correlation between (for example) shareholder rights and the financial structure of firms need not imply that the latter has been caused by the former; the causal flow could just as easily be reversed (Rodrik, 2005). The legal origins approach arrived at an apparent solution to this problem: because nearly all countries have acquired their legal origin by conquest or colonisation and not by choice, legal infrastructure can plausibly be regarded as having an independent causal influence on both legal rules and economic outcomes (La Porta et al., 2008). In a research field plagued by the issue of endogeneity, this was welcomed as a rare example of a truly exogenous effect.

Whether the binary divide between common law and civil law systems can really serve as a proxy for the multiple dimensions of law-making processes at country level is, however, open to question. There is a case for a more systematic unbundling of the legal origin variable, which would better capture heterogeneity in the relative importance of judge-made law and statute as sources of law, within as well as across the principal legal 'families' (Siems and Deakin, 2010:127-128). The claim that legal infrastructure is completely exogenous to the economy is also doubtful. Two-way causal flows can be expected not only in the case of 'parent' systems, whose institutions are presumably, within the terms of legal origins theory itself, endogenous to their own economic developmental path (Deakin and Pistor, 2012), but also in the many instances of countries consciously borrowing or adapting legal institutions from other systems, as opposed to having them imposed upon them from outside (Klerman et al., 2011).

Going further, one of the core methodological assumptions lying behind the legal origins approach, namely that there is a more or less invariant, unidirectional relationship between legal and economic variables, is questionable. As we have seen (Section 2), it is just as plausible to see legal institutions operating through a series of feedback loops with the economy. Legal and economic 'coevolution' implies that broad alignment of legal and economic phenomena over the long run is compatible with a more turbulent and uncertain adjustment path over the short run, as each system responds to 'shocks' or 'perturbations' in its environment (Ahlering and Deakin, 2007).

Coevolution implies an empirical strategy that explicitly takes on board the possibility of two-way causation, and is capable of analysing the timedimension of institutional change. Two-way causation is an ever-present reality in institutional research, but the endogeneity of institutions need not prevent appropriate empirical testing.

Through time-series analysis it is also possible to distinguish between shortrun and long-run effects of legal change. Leximetric time series, in common with many other longitudinal macro-level indicators, are non-stationary (Deakin and Sarkar, 2008; Sarkar and Singh, 2010). This means that they are liable to move 
persistently away from benchmark values in response to external shocks. Where two time series are non-stationary in this sense, they are said to be cointegrated if they are linked by a common, stochastic trend, which can be taken to signify the presence of a relationship between them (Engle and Granger, 1987). Econometric models that estimate these relationships - cointegrated vector autoregression (CVAR) and vector error correction (VEC) models - are appropriate for use when testing for the impact of legal change on the economy and vice versa, because they make it possible to distinguish between short-run and long-run effects (Juselius, 2011). Time-series econometrics also makes it possible to get some idea of the direction of causal flows between the law and the economy. Granger-causality techniques, involving the use of lagged or past values of one or both of the variables of interest (Granger, 1969), can be combined with CVAR models to provide an indication of causal precedence.

Deakin et al. (2012) use the CVAR approach to analyse the relationship between changes in shareholder protection between 1995 and 2005, as measured by the SPI-10 dataset (see Section 3), and financial development indicators contained in the World Bank's financial structure database. The latter provides data on the size of the stock market (measured as stock market capitalisation over GDP), the level of stock market activity as defined by share turnover and the number of listed companies (Beck et al., 2000). Deakin et al. (2012) find that in common law countries and in developing ones, a rise in the SPI was positively correlated to financial development over this period, with the direction of causation running from the legal variables to the financial ones; in the case of developing countries only, there is also evidence of reverse causation. There is no evidence of a financial impact of legal change, or of reverse causation running from financial development to legal reform, in civil law countries.

In the light of the CVAR methodology used in this study, the results can be interpreted as suggesting that legal change has had an independent, longrun causal effect on stock market development, in some national contexts; in common law countries and in the developing world, the equilibrium-adjustment path of the economy was altered by legal intervention. The presence of a reversecausal effect in the developing world suggests that there was local demand for legal reform, generated by internal factors in those countries. The absence of causal flows in either direction in civil law countries suggests that not only was there limited internal demand for legal reforms in their case, but also, once in place, the laws failed to bed down and produce tangible economic effects. Most likely this was because rules originating in the liberal market contexts of the common law world turned out to have little relevance once they were transplanted into the coordinated market economies of the civil law world. However, the exact processes at work in the reception (and apparent rejection) of these legal transplants cannot be discerned from macro-level econometric analysis. To get a clearer picture of what might have been happening on the ground in these countries, case-study analysis is required. 


\section{Combining quantitative analysis with interview-based fieldwork}

To be fully rounded, case studies of legal and related institutional phenomena should combine leximetric and econometric methods with qualitative techniques. Qualitative research can mobilise a wide range of sources, including descriptive statistics, archival research and documentary analysis, as well as various kinds of fieldwork involving interviews and direct observation. It is not only the limitations of quantitative data on institutions that necessitate qualitative approaches, but also the nature of the causal processes at work in institutional change. If institutional phenomena are seen as the outcome of evolutionary processes that are path-dependent and contingent on local factors, it becomes important to identify the role of specific features of social contexts in shaping outcomes. Fieldwork can be used to study non-linear, multivariate causal relationships that are otherwise not fully observable (Poteete et al., 2010: 60-62).

Thus at the core of qualitative research is a particular ontological stance: it posits a social world that is multivariate, complex and open. The role of contingency in shaping social structures can be unveiled by studying a specific case in its local context. Historical and narrative approaches can reveal nonlinear or cumulative causal effects. Talking directly to the actors concerned can clarify issues of sequencing. Longitudinal research, of the kind commonly used in case studies, allows space for findings to emerge in the light of an extended period of observation and data collection. A flexible research design makes it possible to treat issues that quantitative research treats as assumptions, embedded in formal models and statistical tests, as hypotheses for empirical research, to be refuted, or possibly confirmed, by evidence as it emerges from a sequence of interviews (Poteete et al., 2010: 35).

In this vein, Buchanan et al. (2012) use a multiple-methods approach to study the recent evolution of corporate governance institutions in Japan. Their analysis addresses the question of why Japanese corporate governance rules, relations and practices did not, on the whole, converge on the 'global standard' in corporate governance during the 2000s. The study highlights the limits of the law and the potential barriers to the success of legal and other institutional transplants.

Japan adopted a German-law model for its commercial code in the 1880s and so can be classified for this purpose as a civil law system, but most of its modern company laws are American in origin, having been put in place under direct US influence in the early 1950s. On the face of it, Japan's company law is one of the most protective in the world with regard to Type- 1 shareholder rights. The SPI-10 index ranks Japan in the top quintile of countries for this type of shareholder protection, alongside countries such as Canada, the UK and the USA (Siems, 2008). It was against this background that activist investors pursuing strategies based on the maximisation of shareholder returns began to play a more prominent role in the Japanese market in the early 2000s. 
Hedge fund activism has its origins in the 'deal decade' of the USA in the 1980s. Hedge fund activists take large stakes in mostly profitable but undervalued firms with high cash reserves and low external debt, and engage directly with management on issues of capital structure and business strategy. They call for the return of cash surpluses to shareholders in the form of increased dividends and share buy-backs, and encourage firms to increase their leverage. This approach has proved to be a successful and much replicated investment strategy in its original US context, where it is associated with the efficiency gains from enhanced shareholder scrutiny of management (Brav et al., 2008), although there is also evidence that it causes losses to bondholders and does not have a consistently positive effect on firms' operating performance (Klein and Zur, 2009, 2011). In the context of a Japanese market in which, throughout the 2000s, shares in around a fifth of companies listed on the first section on the Tokyo Stock Exchange were trading below book value, and where shareholders' legal rights were on a par with those in the USA, this strategy was widely seen among investors and commentators as apt for transplantation into the Japanese context.

Buchanan et al. (2012) firstly use quantitative methods to analyse hedge funds' interventions in Japanese companies, taking advantage of commercially available firm-level data. Regression analysis indicates that the targeting of firms by activist hedge funds in Japan followed largely the same pattern as that in the USA, suggesting a similarity of investment approach. The analysis shows, however, that capital restructuring in Japanese firms in response to hedge fund interventions was not extensive. It also indicates that firms' financial and operating performance following interventions was not consistently positive (Buchanan et al, 2012: 199-205).

They then use a hand-collected database of activist hedge fund interventions in Japan that they compiled from Japanese press reports and other relevant sources including the Japanese Financial Services Agency's Electronic Disclosure for Investors' Network (EDINET) database. This provides a more detailed case-study account of hedge fund interventions than could be obtained from commercial databases. It reveals that a period of generally high returns from activism during the period 2000-2004 was followed by one of falling returns, accompanied by growing managerial resistance to activist tactics, from 2004 onwards, culminating in a staged withdrawal of activist funds from the Japanese market after 2008 (Buchanan et al., 2012: 205-209).

The third source of data in this study consists of just over 100 interviews with managers of Japanese listed companies, investors (including hedge funds), trade association representatives, legal experts, regulators and policy-makers, carried out between 2003 and 2010. The 20 or so firms in the interview sample were visited repeatedly over the period of the study, to provide a longitudinal view of changes in perceptions of corporate governance rules and practices. With the addition of these fieldwork-based, interview data, the local institutional 
context to the failure of hedge fund activism in Japan starts to come into focus.

The interview materials make clear what the leximetric and econometric analyses only hint at, which is that, in Japan, shareholders do not generally act as principals and managers do not act as their agents. Hedge fund managers explicitly adopted the language of agency theory, in which many of them had been trained, when explaining their investment strategies: Japanese managers, they argued, should respond to pressures for enhanced shareholder returns through increased dividends and share buy-backs, since to do so was not only an acknowledgement that shareholders were the 'true owners' of the firm, but also a means of improving the firms' financial and organisational efficiency. Executives in the targeted firms, on the other hand, openly rejected the language of shareholder primacy, claiming that they had responsibilities to multiple groups of stakeholders, including employees and customers. Far than seeing themselves as accountable to shareholders, managers sought to recruit shareholders who would support them in attempting to grow the firm over the medium to long term. Strikingly, even shareholders tended to share the view that Japanese companies should not be run purely to maximise shareholder returns. Although foreign investors were mostly investing for returns, domestic shareholders, many of whom were investing to maintain business relationships, viewed the hedge funds as destroying value over the longer term. Hedge fund managers recognised this, complaining that domestic Japanese shareholders, whose support they needed but mostly did not obtain, were 'conflicted' in their dealings with them (Buchanan et al., 2012: chs. 9-11).

This example shows how qualitative research, based on repeated, in-depth interviews with corporate actors, provides access to information that is simply not available from quantitative analysis. The leximetric analysis of Japanese 'law on the books' portrays a corporate governance environment that the hedge funds should have found highly congenial. That the contrary was the case suggests that the law governing shareholder rights, in this case, was only a marginal factor in shaping economic behaviour and outcomes. The econometric analysis of firmlevel financial data complicates the picture by showing that hedge funds active in the Japanese market targeted similar firms to those in which they successfully invested in the USA, but that the outcomes were different in the two countries. The econometric analysis points to a pattern but cannot explain it. The rich data revealed by the qualitative studies go a long way to providing that explanation: the standard principal-agent model of the firm has limited traction in the Japanese context, where managers see themselves more as trustees or stewards of the firm than as agents of the shareholders. The Japanese firm rests on a model of internally orientated governance, in which monitoring by informed insiders takes the place of the external monitoring that is assumed in the standard principalagent model. The Japanese model, in its own environment, is stable, and resistant to practices, such as hedge fund activism, transplanted from other contexts. 


\section{Conclusions}

In this paper we have looked at various methodological innovations that are making it possible to test some of the claims made by institutional theory concerning the coevolution of legal systems and economic forms, including the business enterprise. So-called 'leximetric' techniques are providing comparative data on legal systems in a novel form, facilitating statistical analysis. Econometric methods, in particular those using cointegration-based approaches, provide techniques for studying the interaction of legal rules with financial variables over extended time periods, and for distinguishing between short-term and long-term effects of legal change. These quantitative techniques nevertheless have their limits. As a case study of recent developments in Japanese corporate governance demonstrated, field work and face-to-face interviewing are needed to clarify the role of informal institutions, beyond the reach of formal laws and regulations, in shaping actors' behaviour. The patterns revealed in Japan may exist elsewhere; but a purely quantitative approach might never uncover them. A multiple-methods approach of the kind recommended by Poteete et al. (2010) should therefore be understood as the methodological state of the art for institutional research.

A further implication of our analysis is that when empirical methods are brought to bear on questions of institutional evolution, some of the claims made in the literature on law and finance do not stand up. In particular, claims that corporate governance works best when managers act as shareholders' agents, that civil law institutions are inherently less adapted to the needs of market economies than common law ones and that legal systems worldwide are converging on a supposedly more efficient common law model of legal and economic governance, are not borne out by recent analyses. As improved empirical methods are brought to bear on these issues, we may expect to become better informed on the role institutions play in supporting economic development and growth, and on the scope for legal reforms to improve economic outcomes.

\section{Acknowledgements}

We are grateful for financial support from the Economic and Social Research Council (grant ES/J012491/1, 'Law, Development and Finance in Rising Powers').

\section{References}

Acemoglu, D. and S. Johnson (2005), 'Unbundling Institutions', Journal of Political Economy, 113(5): 949-995.

Ahlering, B. and S. Deakin (2007), 'Labor Regulation, Corporate Governance, and Legal Origin: A Case of Institutional Complementarity?', Law \& Society Review, 41(4): 865908. 
Anderson, H., P. Gahan, R. Mitchell, I. Ramsay, and M. Welsh (2012), 'Worker and Investor Protection in Australia: A Longitudinal Analysis', Sydney Law Review, 34(3): 573-585.

Aoki, M. (2007), 'Endogenizing Institutions and Institutional Change', Journal of Institutional Economics, 3(1): 1-31.

Aoki, M. (2010), Corporations in Evolving Diversity: Cognition, Governance and Institutions, Oxford/New York: Oxford University Press.

Armour, J., S. Deakin, P. Lele, and M. Siems (2009a), 'How Do Legal Rules Evolve: Evidence from a Cross-Country Comparison of Shareholder, Creditor and Worker Protection', American Journal of Comparative Law, 57(3): 579-629.

Armour, J., S. Deakin, P. Sarkar, M. Siems, and A. Singh (2009b), 'Shareholder Protection and Stock Market Development: An Empirical Test of the Legal Origins Hypothesis', Journal of Empirical Legal Studies, 6(2): 343-381.

Armour, J., H. Hansmann, and R. Kraakman (2009c), 'The Essential Features of Corporate Law', in R. Kraakman, J. Armour, P. Davies, L. Enriques, H. Hansmann, G. Hertig, K. Hopt, H. Kanda, and E. Rock (eds.), The Anatomy of Corporate Law, Oxford: Oxford University Press, pp. 1-34.

Beck, T., A. Demirgüç-Kunt, and R. Levine (2000), 'A New Database on Financial Development and Structure', World Bank Economic Review, 14: 597-605.

Braithwaite, J. (2006), 'Responsive Regulation and Developing Economies', World Development, 34(5): 884-898.

Brav, A., W. Jiang, F. Partnoy, and R. Thomas (2008), 'Hedge Fund Activism, Corporate Governance and Firm Performance', Journal of Finance, 63(4): 1729-1775.

Buchanan, J., D. H. Chai, and S. Deakin (2012), Hedge Fund Activism in Japan: The Limits of Shareholder Primacy, Cambridge, UK: Cambridge University Press.

Chor, D. and R. Freeman (2005), 'The 2004 Global Labour Survey: Workplace Institutions and Practices around the World', NBER Working Paper No. 11598.

Coase, R. (1988), The Firm, the Market and the Law, Chicago. IL: University of Chicago Press.

Cooter, R. and T. Ginsberg (2003), 'Leximetrics: Why the Same Laws are Longer in Some Countries than Others', Working Paper No. LE03-012, College of Law, University of Illinois.

Deakin, S. (2003), 'Enterprise-Risk: The Juridical Nature of the Firm Revisited', Industrial Law Journal, 32(42): 97-113.

Deakin, S. and F. Carvalho (2011), 'System and Evolution in Corporate Governance', in P. Zumbansen and G.-P. Calliess (eds.), Law, Economics and Evolutionary Theory, Cheltenham: Edward Elgar, pp. 111-130.

Deakin, S. and K. Pistor (2012), 'Introduction', in S. Deakin and K. Pistor (eds.), Legal Origin Theory, Cheltenham: Edward Elgar.

Deakin, S. and P. Sarkar (2008), 'Assessing the Long-Run Economic Impact of Labour Law Systems: A Theoretical Reappraisal and Analysis of New Time-Series Data', Industrial Relations Journal, 39(6): 453-487.

Deakin, S., P. Sarkar, and A. Singh (2012), 'An End to Consensus? The Selective Impact of Corporate Law Reform on Financial Development', in M. Aoki, K. Binmore, S. Deakin, and H. Gintis (eds.), Complexity and Institutions: Markets, Norms and Corporations, Basingstoke: Palgrave Macmillan.

Djankov, S., R. La Porta, F. Lopez-de-Silanes, and A. Shleifer (2008), 'The Law and Economics of Self-Dealing', Journal of Financial Economics, 88(3): 430-465.

Ehrlich, E. [1936] (2002), Fundamental Principles of the Sociology of Law, trans. W. Moll, Brunswick, NJ: Transaction Books. 
Engle, R. and C. Granger (1987), 'Cointegration and Error Correction: Representation, Estimation, and Testing', Econometrica, 55(2): 251-276.

Fagernäs, S. (2010), 'Labor Law, Judicial Efficiency and Informal Employment in India', Journal of Empirical Legal Studies, 7(2): 282-321.

Gindis, D. (2009), 'From Fictions and Aggregates to Real Entities in the Theory of the Firm', Journal of Institutional Economics, 5(1): 25-46.

Granger, C. (1969), 'Investigating Causal Relations by Econometric Methods and CrossSpectral Methods', Econometrica, 37(3): 424-438.

Greif, A. (2006), Institutions and the Modern Economy: Lessons from Medieval Trade, Cambridge, UK: Cambridge University Press.

Hall, P. and D. Soskice (2001), 'An Introduction to Varieties of Capitalism', in P. Hall and D. Soskice (eds.), Varieties of Capitalism: Sources of Comparative Advantage, Oxford: Oxford University Press.

Hayek, F. (1982), Law, Legislation and Liberty: A New Statement of the Liberal Principles of Justice and Political Economy, London: Routledge and Kegan Paul.

Hédoin, C. (2012), 'Linking Institutions to Economic Performance: The Role of MacroStructures in Micro-Explanations', Journal of Institutional Economics, 8(3): pp. 327349.

Hodgson, G. (2006), 'What are Institutions?', Journal of Economic Issues, 40(1): 2-25.

Juselius, K. (2011), 'Time to Reject the Privileging of Economic Theory Over Empirical Evidence? A Reply to Lawson', Cambridge Journal of Economics, 35(2): 423-436.

Kaufmann, D., A. Kraay, and M. Mastruzzi (2008), 'Governance Matters VII: Aggregate and Individual Governance Indicators for 1996-2007', World Bank Policy Research Working Paper No. 4654, Washington, DC: World Bank.

Klein, A. and E. Zur (2009), 'Entrepreneurial Shareholder Activism: Hedge Funds and Other Private Investors', Journal of Finance, 64(1): 187-229.

Klein, A. and E. Zur (2011), 'The Impact of Hedge Fund Activism on the Target Firm's Existing Bondholders', Review of Financial Studies, 24(5): 1735-1771.

Klerman, D., P. Mahoney, H. Spamann, and M. Weinstein (2011), 'Legal Origin or Colonial History?', Journal of Legal Analysis, 3(2): 379-409.

La Porta, R., F. Lopez-de-Silanes, and A. Shleifer (2008), 'The Economic Consequences of Legal Origins', Journal of Economic Literature, 46(2): 285-332.

La Porta, R., F. Lopez-de-Silanes, A. Shleifer, and R. Vishny (1998), 'Law and Finance', Journal of Political Economy, 106(6): 1113-1155.

Lele, P. and M. Siems (2007), 'Shareholder Protection: A Leximetric Approach', Journal of Corporate Law Studies, 7(1): 17-50.

Luhmann, N. [1993] (2004), Law as a Social System, Klaus Ziegert (trans.), F. Kastner, R. Nobles, D. Schiff, and R. Ziegert (eds.), Oxford: Oxford University Press.

North, D. (1990), Institutions, Institutional Change and Economic Performance, Cambridge, UK: Cambridge University Press.

Ostrom, E. (2005), Understanding Institutional Diversity, Princeton, NJ: Princeton University Press.

Poteete, A., M. Janssen, and E. Ostrom (2010), Working Together: Collective Action, the Commons, and Multiple Methods in Practice, Princeton, NJ: Princeton University Press.

Robé, J. P. (2011), 'The Legal Structure of the Firm', Accounting, Economics and Law: A Convivium, 1(1), Article 5, doi: 10.2202/2152-2820.1001.

Rodrik, D. (2005), 'Why We Learn Nothing by Regressing Economic Growth on Policies', Working Paper, Department of Economics, Harvard University. 
Sarkar, P. and A. Singh (2010), 'Law, Finance and Development: Further Analyses of Longitudinal Data', Cambridge Journal of Economics, 34(2): 325-346.

Shirley, M. (2013), 'Measuring Institutions: How to be Precise Though Vague', Journal of Institutional Economics, 9(1): pp. 31-33.

Shleifer, A. and R. Vishny (1997), 'A Survey of Corporate Governance', Journal of Finance, 52(2): 737-783.

Siems, M. (2008), 'Shareholder Protection Around the World ("Leximetric II")', Delaware Journal of Corporate Law, 33(1): 111-147.

Siems, M. and S. Deakin (2010), 'Comparative Law and Finance: Past, Present and Future Research', Journal of Institutional and Theoretical Economics, 166(1): 120-140.

Spamann, H. (2010), 'The “Antidirector Rights Index” Revisited', Review of Financial Studies, 23(2): 467-486.

Voigt, S. (2012), 'How to Measure the Rule of Law', Kyklos, 65(2): 262-284.

Voigt, S. (2013), 'How (Not) to Measure Institutions', Journal of Institutional Economics, 9(1): pp. 1-26.

Williamson, O. (1985), The Economic Institutions of Capitalism, New York: Free Press.

Zweigert, K. and H. Kötz [1992] (1998), Introduction to Comparative Law, 3rd edn, Tony Weir (trans.), Oxford: Oxford University Press. 